\title{
MUHAMMADIYAH DAN SALAFISME: SEBUAH SURVEI SINGKAT TENTANG TITIK TEMU DAN TITIK SETERU
}

Pradana Boy ZTF

\section{Abstrak}

Di antara banyak tantangan kontemporer yang dihadapi oleh Muhammadiyah adalah penetrasi pemikiran dan gerakan Islam lain yang memiliki persinggungan ideologis dengan Muhammadiyah. Di antara banyak gerakan itu, Salafisme adalah salah satunya. Penetrasi Salafisme ke dalam Muhammadiyah memang telah menghadirkan sikap dan respons yang beragam, utamanya di kalangan Muhammadiyah sendiri. Sementara dari kalangan lain, tidak jarang muncul pula identifikasi Muhammadiyah dengan salafisme dan bahkan radikalisme. Seringkali, respons itu bersifat artifisial dan teknis, sementara respons yang mendalam dan detail cenderung sulit ditemukan. Tulisan ini merupakan survei awal sederhana untuk memetakan dialektika Muhammadiyah dan Salafisme. Sebagai survei singkat, tulisan ini belum sepenuhnya masuk ke dalam perbandingan yang detail dan mendalam. Akan tetapi, tulisan ini menawarkan sebuah cara pandang khas tentang bagaimana memahami dialektika Muhammadiyah dan Salafisme dewasa ini.

Kata kunci: Muhammadiyah, Salafisme, Wahhabisme, Al-Qur'an 
Belakangan ini, pembahasan tentang hubungan antara Muhammadiyah dan salafisme meningkat cukup tajam. Beberapa persoalan yang sering dibincangkan adalah tentang pengaruh salafisme ke dalam gerakan dan identitas organisasi Muhammadiyah; dominasi salafisme dalam model dan orientasi keberagamaan Muhammadiyah; pengaruh salafisme dalam turut menentukan warna gerak dan posisi politik Muhammadiyah; hingga kecenderungan anggota Muhammadiyah untuk menjadi lebih "salafi," setidaknya dalam konteks simbolik. Diyakini, gejala-gejala itu semakin hari semakin nyata, dan telah menghadirkan kekhawatiran di kalangan anggota Muhammadiyah.

Menyangkut Muhammadiyah dan salafisme, secara umum ada dua cara pandang yang berlawanan. Kalangan internal Muhammadiyah menganggap salafisme sebagai hal yang tidak identik dengan Muhammadiyah, meskipun ada elemen-elemen tertentu yang mempertemukan keduanya. Sementara sejumlah kalangan dari luar melihat Muhammadiyah tidak lain adalah salafisme, utamanya Wahhabisme. Bahkan dalam banyak hal Muhammadiyah juga dikaitkan dengan ekstremisme dan radikalisme. Kedua pandangan ini samasama tidak tepat. Menganggap Muhammadiyah sama sekali berbeda dengan salafisme, sama tidak cermatnya dengan menganggap Muhammadiyah sebagai seratus persen salafi. Saya ingin mengibaratkan hubungan dan pergulatan antara Muhammadiyah dan salafisme ini sebagai "bukan kembar siam.” Maknanya, keduanya tidak benar-benar identik, tetapi juga juga tidak benar-benar berbeda dan terpisah sama sekali.

Di kalangan internal Muhammadiyah sendiri, ketika sudah menyangkut perbincangan tentang salafisme, dan lebih khusus lagi salah satu varian dalam salafisme, yaitu Wahhabisme, seringkali terjadi kegamangan dalam memberikan respons. Misalnya, karena kepentingan tertentu, ada kelompok-kelompok yang selalu berusaha dengan keras melakukan identifikasi Muhammadiyah dengan Wahhabisme, bahkan radikalisme. Pada umumnya, respons yang lahir dari sejumlah kalangan di Muhammadiyah bersifat umum saja, dan tak jarang juga defensif. Misalnya, bahwa tak elok dan tak tepat menyandingkan Muhammadiyah dengan Wahhabisme dan radikalisme, karena Muhammadiyah bukan keduanya dan Muhammadiyah memiliki metode, corak dan warna keagamaannya sendiri. Namun sayangnya, jawaban "tak elok" atau "tak tepat" itu seringkali tidak dibarengi dengan identifikasi yang lebih khusus dan detail, tentang wilayah di mana Muhammadiyah memang bersinggungan dengan salafisme dan atau Wahhabisme dan pada wilayah mana yang tidak. Atau jika memang tidak ada sama sekali, bagaimana menjelaskan anatomi keduanya, 
agar ketiadaan persinggungan itu juga terang. Bukan atas dasar asumsi dan perkiraan.

\section{Respons Intelektual Muhammadiyah}

Dalam kaitan dengan penetrasi salafisme ke Muhammadiyah yang belakangan ramai ini, Biyanto, pengurus Pimpinan Wilayah Muhammadiyah Jawa Timur, dan guru besar Universitas Islam Negeri Sunan Ampel, Surabaya, pernah mengungkap gejala ini ke dalam sebuah tulisan. Pilihan Biyanto menuangkan keresahan tersebut dalam tulisan sangat baik, sehingga fenomena itu tidak hanya menjadi rasan-rasan, tetapi bisa didiskusikan secara ilmiah, dengan argumentasi dan bukti. Dalam sebuah tulisan berjudul Menyikapi Tren Salafisme di Muhammadiyah (pwmu.co, 16/09/2019), Biyanto memberikan sejumlah contoh pengaruh salafisme di Muhammadiyah itu. Misalnya, tentang semakin maraknya pegawai-pegawai perempuan di lingkungan Muhammadiyah yang bercadar atau para pegawai laki-laki yang memakai celana cingkrang.

Tulisan Biyanto ini seperti mewakili keresahan banyak pihak dalam Muhammadiyah yang masih segan untuk mengungkapkan fenomena tersebut secara terbuka. Tentu banyak faktor yang menyebabkan keengganan tersebut. Bisa jadi karena hal itu akan memberikan pengaruh yang kurang baik kepada persatuan internal di Muhammadiyah sebagai organisasi. Atau sangat mungkin mereka yang dikelompokkan sebagai salafi dalam Muhammadiyah itu lalu merasa tidak nyaman berada dalam lingkaran Muhammadiyah, dan kemudian bisa menyebabkan gesekan tidak sehat.

Meskipun bersifat sangat elementer, tulisan Biyanto berhasil membuka kotak Pandora. Menyusul fenomena yang diungkapkan Biyanto itu, lalu bermunculan tulisan-tulisan lain yang berkaitan dengan salafisme di berbagai media yang diterbitkan oleh Muhammadiyah. Robby Karman menulis Membentengi Muhammadiyah dari Paham Salafi (ibtimes.id, 26 September 2019). Nurbani Yusuf menulis artikel Manhaj Salafi Anti-Tesis Manhaj Muhammadiyah (ibtimes.id, 07/10/2019) dan Salafi Hari ini adalah Utsaiminiyah (ibtimes.id, 08/10/2019). Sementara, Nurfarid menulis Islam Reformis: Dari Salafi Tekstual ke Salafi Rasional (ibtimes.id, 02/10/2019). Hasnan Bachtiar juga meramaikan diskusi dengan menulis artikel Lima Varian Salafisme di Indonesia. Tak hanya tulisan, diskusidiskusi tentang Muhammadiyah dan salafisme pun lalu ramai digelar. 
Namun, dari tulisan-tulisan lepas yang disebutkan di atas, ada hal yang tertinggal. Sejauh ini, hanya tulisan Hasnan Bachtiar dan Nurfarid yang telah sedikit menyentuh gambaran yang relatif gamblang tentang anatomi, variasi dan hakikat salafisme dan mengapa serta bagaimana ia bisa menghadirkan ancaman bagi Muhammadiyah. Selain kedua artikel itu, kecenderungan umumnya adalah menganggap salafisme sebagai suatu entitas tunggal yang menjadi ancaman bagi Muhammadiyah. Akibatnya, penghadapan Muhammadiyah dan salafisme menjadi ciri umum yang sering tidak bisa dihindari. Tulisan Nurbani Yusuf, misalnya, menganggap salafisme sebagai antitesis manhaj Muhammadiyah. Kesimpulan seperti ini kurang tepat, bukan hanya karena ada elemen-elemen pemikiran salafi di Muhammadiyah, tetapi juga karena kesimpulan serupa muncul tanpa ada parameter metodologis yang pas untuk mengukur keduanya. Demikian juga ketika Nurbani menyebut salafisme adalah identik dengan Utsaiminiyah, ia melupakan varian-varian dalam salafisme yang ternyata sangat banyak, dan tak semuanya Utsaiminiyah. Karena, baik sebagai konsep pemikiran maupun gerakan, salafisme telah mengalami perkembangan yang cukup lama, sehingga memiliki konteks dan konotasi yang tidak tunggal. Tulisan Nurfarid sedikit mengungkap soal ragam orientasi salafi ini, meskipun masih sangat terbatas.

Perdebatan yang telah menggelinding ini, jika tidak diarahkan kembali ke rel awalnya, bisa berbahaya, liar dan tak terarah. Karena ibaratnya, kita sedang membahas dan membandingkan dua hal, sementara gambaran, detail dan hakikat kedua hal tersebut masih samar. Jikapun tak samar, baru satu yang diketahui secara pasti, yaitu Muhammadiyah. Sementara tentang salafisme, dari beberapa tulisan itu, saya menangkap belum ada pemahaman yang memadai. Panjang lebar sudah pembahasan tentang Muhammadiyah dan salafisme dilakukan, tetapi justru hal-hal yang mendasar terlupakan.

Ini sebenarnya bisa dimaklumi. Bagaimanapun, salafi telah menjadi semacam catchword dalam diskursus tentang wacana dan gerakan Islam di Indonesia belakangan ini. Tetapi pemahaman umum tentang salafisme yang cenderung tunggal (misalnya menganggap salafisme semata-mata identik dengan satu kelompok tertentu), tentu akan menjadikan pemahaman tentang salafisme melupakan fakta keragaman salafisme itu. Peristiwa yang saya alami berikut ini, barangkali bisa menjadi ilustrasi. Saat mempertahankan disertasi tentang fatwa di tiga lembaga (Majelis Ulama Indonesia, Majelis Tarjih Muhammadiyah, dan Lajnah Bahtsul Masail NU) pada tahun 2015, salah satu penguji, Profesor Syed Farid Alatas memberikan sebuah pertanyaan berkaitan dengan salafisme ini. 
"Mengapa Anda tidak mengatakan secara eksplisit bahwa unsur-unsur salafisme mempengaruhi pola pikir dan ideologi Majelis Ulama' Indonesia (MUI) saat ini? Dari kajian yang Anda lakukan, menurut saya, jelas sekali bahwa fatwafatwa MUI sangat dipengaruhi oleh salafisme.”

Pada saat itu, saya menjawab bahwa saya tidak secara eksplisit menyebutkan pengaruh salafisme dalam fatwa-fatwa MUI karena istilah salafisme ini dalam konteks Indonesia maupun global merupakan sebuah istilah yang mengandung banyak sekali perdebatan dan memiliki banyak makna konotatif. Tidak ada definisi dan konteks tunggal atas istilah salafi, sehingga menyebut MUI dipengaruhi oleh salafisme akan menimbulkan banyak sekali pertanyaan tentang aspek, model, jenis, atau tipe salafi apa yang dimaksudkan. Tentu saja, yang saya fahami, Syed Farid Alatas memaksudkan salafi dalam konteks ini sebagai orientasi pemikiran. Lebih jauh, lalu saya mengajukan satu pemikiran bahwa dalam konteks Indonesia, salafisme bisa dimaknai dalam sejumlah konteks, yaitu: a) Salafisme sebagai Periode Sejarah; b) Salafisme sebagai Orientasi Pemikiran; c) Salafisme sebagai Model Pendidikan; dan d) Salafisme sebagai Gerakan atau Kelompok Keagamaan. Prof. Farid Alatas menerima pandangan saya itu dan meminta saya memasukkannya dalam revisi disertasi.

Tulisan ini ingin menyentuh wilayah-wilayah dasar itu dengan menggunakan ragam cara pandang terhadap salafisme, tepatnya lagi akan membahas salafisme secara singkat dua dari keempat konteks dan cara pandang di atas, kemudian melakukan perbandingan dan analisis hubungan antara Muhammadiyah dan salafisme.

\section{Salafisme sebagai Fase Sejarah}

Jika salafisme hari ini pada umumnya dirujuk sebagai nama sebuah kelompok keagamaan dengan orientasi khusus, sebuah cara pandang menarik yang berbeda dengan pandangan umum itu, ditawarkan oleh Muhammad Saad Ramadhan al-Bathi. Menurutnya, tidak seharusnya melihat salafisme sebagai aliran atau mazhab keagamaan, karena pada dasarnya salafiyyah adalah marhalah zamaniyyah mubarakah. Maka, dalam al-Salafiyah: Marhalah Zamaniyyah Muborakah La Mazhabun Islamiyyun, al-Bathi menghubungkan istilah salafiyah dengan fase dalam sejarah umat Islam. 
Untuk memahami pandangan al-Bathi ini, pemahaman tentang makna istilah salaf secara kebahasaan menjadi sangat penting. Secara kebahasaan, al-salaf bermakna hal "yang telah lalu." Karena menyangkut waktu, maka makna "yang telah lalu" itu bisa bermakna relatif, demikian menurut al-Bathi. "Masa lalu" sangat erat kaitannya dengan masa "sebelum" dan "sesudah." Maka, apa yang disebut "masa lalu" pada hari ini adalah zaman sebelum hari ini. Namun, hari ini adalah potensi "masa lalu" pada masa yang akan datang.

Senada dengan al-Bathi, dalam Ma Hiya al-Salafiyyah? Abd-u-LLah bin Abd alRahim al-Bukhari (2012) menulis bahwa kata (kalimah) yang tersusun dari huruf sin, lam dan fa' pada umumnya mengandung makna hal-hal yang terdahulu. Maka, dengan pendekatan kebahasaan, penulis ini memaknai al-salafiyyah sebagai: "man taqaddamaka wa sabaqaka fi al-sinni wa al-fadhli..." yakni mereka yang mendahuluimu dalam hal umur dan keutamaan (h. 14).

Namun, kedua penulis ini juga menyadari bahwa di luar makna kebahasaan, istilah salafiyah juga memiliki konotasi khusus dalam sejarah Islam. Berkaitan dengan hal inilah, baik Ramadhan al-Bathi maupun Abd al-Raham al-Bukhari beranjak dari sebuah hadits Rasulullah tentang zaman atau masa terbaik bagi umat Islam. Al-Buthi mengajukan definisi: "al-qur'an al-tsalatsah al-ala min umri hadzihi al-ummah al-Islamiyyah..." (h. 9), yakni tiga periode pertama dari umur umat Islam. Ini didasarkan pada hadits Rasulullah Riwayat Bukhari dan Muslim yang bersumber dari Ibn Mas'ud: "Khairu al-nasi qarna, tsumma al-ladzana yalanahum tsumma al-ladzana yalanahum..." Bahwa sebaik-baik manusia adalah yang hidup pada zaman Nabi Muhammad, kemudian orang-orang yang datang pada masa berikutnya, dan orang-orang yang datang pada zaman berikutnya lagi.

Selain hadits ini, dari Shahih Muslim berdasarkan riwayat dari 'Aisyah terdapat sebuah hadits yang berbunyi: "Seseorang bertanya kepada Rasulullah: "Siapakah manusia yang paling baik?" Rasulullah menjawab: "Al-Qurunu al-ladzi ana fihi tsumma al-tsani, tsumma al-tsalits (Satu masa yang aku ada di dalamnya kemudian masa kedua, lalu masa ketiga)."

Identifikasi tentang generasi-generasi Muslim terbaik di masa awal inilah yang kemudian melahirkan istilah salaf al-shalih(orang-orang shalih yang hidup pada masa terdahulu). Secara umum, umat Islam menerima hadits ini sebagai keterangan tentang tiga masa terbaik dalam sejarah umat Islam. Namun, hal yang menarik adalah baik al-Bathi maupun al-Bukhari mengajukan sebuah pertanyaan menarik: apakah tiga zaman terbaik dalam kehidupan umat Islam itu hanya terbatas pada tiga zaman awal Islam tersebut. Atau dengan kata lain 
apakah semua orang yang berada dalam zaman tersebut dengan sendirinya adalah orang yang utama? Tegasnya lagi, apakah mereka yang hidup pada zaman itu dengan sendirinya bisa disebut sebagai salaf al-shalih. Lebih mendalam lagi, al-Bathi mengajukan pertanyaan apakah tiga masa yang disebutkan itu bersifat berurutan ('ala tartab), ataukah ia mengandung makna majma' al-muslimina alladzina 'Isya fi tilka al-qur'an? Yakni seluruh umat Islam yang hidup pada zaman yang tiga itu. Atau yang dimaksud adalah seluruh individu-individu Muslim tanpa terkecuali?

Al-Bathi mengungkapkan bahwa terdapat perbedaan pandangan dalam memahami persoalan ini. Tetapi jumhur ulama' berpandangan bahwa yang mendapatkan kebaikan dari tiga zaman pertama ini adalah seluruh individu Muslim yang hidup pada zaman yang tiga tersebut. Perbedaan, kata Bathi, hanya terjadi pada derajat di antara masing-masing individu yang disesuaikan dengan ketakwaan dan konsistensi (istiqamah).

Abd al-Rahim al-Bukhari memberikan jawaban tegas atas pertanyaan itu dengan mengatakan bahwa tidak berarti semua orang yang hidup pada tiga zaman itu dengan sendirinya bisa disebut dengan salafi. "Hidup di zaman yang terdahulu saja tidak cukup untuk menjadikan seseorang sebagai al-salaf al-shalih," kata alBukhari. Maka, menurutnya, istilah ini merujuk hanya kepada sahabat yang tidak hanya bertemu dengan Nabi Muhammad, tetapi memiliki kualifikasi yang oleh Abd al-Rahm al-Bukhari disebut dengan muwafaqatun li al-kitabi wa al-sunnah wa fahmi al-shahabah (memiliki sikap dan pemahaman yang sejalan dengan kitab dan sunnah serta pemahaman para sahabat) (h. 15).

Sejalan dengan pandangan ini, al-Allamah Syaikh Muhammad Amman dalam al-Sifat al-Ilahiyyah fi Dhaw'i al-Kitabi wa Sunnati, mengajukan sebuah definisi tentang salafiyah. Menurutnya, salafiyah adalah ash hiba rasilillah alladzina hadlari 'ashrahu, fa-akhadli minhu hidla al-dina mubisyaratan ghadhan thariyyan fi ushilihi wa furi'ihi... (h. 57). (Bahwa salafi adalah sahabat-sahabat Rasulullah yang bertemu dengan masa Rasulullah, belajar agama secara langsung darinya baik dalam halhal yang bersifat pokok maupun cabang).

Namun, dalam pandangan Bathi, tidak jarang pemahaman tentang istilah salafiyyah tidak mempertimbangkan aspek-aspek mendasar ini. Lalu dengan tegas, al-Bathi mengemukakan sebuah pandangan bahwa di antara kesalahan dalam memaknai kalimat al-salaf adalah ketika istilah ini dimaknai secara berbeda dengan konteks sejarah pembentukan syariat dan pemikiran Islam. Tegasnya, pandangan yang menganggap salafiyah sebagai corak baru yang 
mewakili segolongan tertentu dari umat Islam yang memiliki pemahaman tertentu yang justru tidak dilakukan oleh mereka yang disebut sebagai salafi itu, sehingga nampak sebagai sebuah kelompok baru.

Dengan berbagai argumentasi yang detail dan mendalam, Said Ramadhan alBathi pada akhirnya menyimpulkan bahwa salafiyah bukanlah nama sebuah mazhab atau kelompok dalam Islam. Tidak lain, salafiyah atau salafisme adalah salah satu masa sejarah yang penuh berkah atau yang dalam bahasa al-Bathi disebut sebagai marhalah tarikhiyyah mubarakah. Dengan tegas, al-Buthi menolak identifikasi salafiyah dengan kelompok tertentu. Ia menulis: fain qashadta biha jama'atun Islamiyyatun dzita manhajin mu'ayyanin khasun biha yatamassaku bihi man syi'a liyashbaha bidzalika muntasiban ilaiha mandzhuwiyyan tahta liwaiha, fatilka idzan ihda al-bida'i al-mustahditsah ba'da rasalillah sallallahu 'alaihi wassalam (h. 23).

(Jika yang Anda maksud dengan salafiyah adalah golongan dalam Islam yang memiliki metode tersendiri yang dijadikan sebagai pegangan bagi mereka yang ingin menjadi bagian dari golongan itu, maka itu tidak lain adalah salah satu bentuk bid'ah yang lahir setelah zaman Rasulullah SAW).

Dengan demikian, apa yang bisa disimpulkan adalah memahami makna salafiyyah sebagai satu fase dalam sejarah sangatlah penting. Di luar persoalan, apakah seseorang setuju atau tidak dengan pandangan para pemikir yang berpegang pada pandangan ini, menghadirkan pemahaman salafiyyah sebagai fase sejarah ini akan memberikan pandangan tentang bagaimana sesungguhnya kesinambungan syari'at dan perkembangan pemikiran di kalangan umat Islam terjadi. Dengan demikian, dalam menghadirkan pemahaman atas aspekaspek keagamaan yang lebih luas, umat tidak terjebak pada romantisisme yang ahistoris. Sikap seperti inilah yang kadang-kadang menjadi penghalang untuk memahami sejarah sebagai inspirasi dan model untuk membangun kesinambungan di masa-masa yang akan datang.

\section{Salafisme sebagai Orientasi Pemikiran Keagamaan}

Pemikir Muslim seperti Said Ramadhan al-Bathi dan Abdullah al-Bukhari cenderung tidak setuju menganggap salafisme sebagai kelompok keagamaan, dengan sejumlah pertimbangan. Namun demikian, secara faktual, kita tidak bisa memungkiri bahwa salafisme pada hari ini telah menjadi suatu orientasi keagamaan khas yang memiliki corak dan sikap tersendiri atas berbagai persoalan. 
Karena itu, perlu kiranya memahami salafisme sebagai orientasi pemikiran ini dengan menampilkan anatomi pemikiran kelompok tersebut. Tentu saja, sebagai kelompok atau gerakan, salafisme juga bukan komunitas yang bersifat tunggal. Namun, ada doktrin dan anatomi dasar yang bisa ditemukan pada semua kelompok salafi. Pada tulisan ini, saya akan membahas anatomi dasar salafisme sebagai orientasi pemikiran, lalu secara sekilas membandingkannya dengan konteks Muhammadiyah.

Perbandingan dengan Muhammadiyah merupakan hal yang penting, karena sebagaimana telah disinggung pada tulisan terdahulu, seringkali terjadi identifikasi Muhammadiyah dan salafisme secara serampangan. Perbandingan ini diharapkan bisa memberikan gambaran yang relatif gamblang tentang hubungan Muhammadiyah dan salafisme, pada titik mana keduanya memiliki persamaan, dan pada titik mana keduanya tidak memiliki persamaan sama sekali.

Para ahli tidak selalu sama dalam mendeskripsikan salafisme. Menurut Syaikh Muhammad al-Shalih Utsaimin, al-Salafiyatu hiya ittiba'u manhaji al-nabiy shalla Llahu alaihi wa sallam wa ashibihi, liannahum salafuna taqaddamu 'alaina, fa ittiba'uhum huwa al-salafiyyah, wa amma ittakhidu al-salafiyati ka manhajin khasin yunfaridu bihi al-insanu. Bahwa yang dimaksudkan dengan salafisme adalah mengikuti manhaj (metode) Muhammad SAW dan sahabat-sahabatnya karena mereka lebih dahulu dari kita. Maka mengikuti mereka, itulah yang disebut dengan salafisme. Sedangkan menjadikan salafisme sebagai metode khusus, akan menjadikan seseorang berbeda dengan orang lainnya.

Mohammed bin Ali dan Muhammad Saiful Alam Shah bin Sudiman (2016), dalam Salafis and Wahhabis: Two Sides of the Same Coin? Memberikan batasan tentang salafisme sebagai berikut: "The ideology of Salafism and Wahhabism is built upon a narrowly defined religious text. Methodologically, they are literalist and puritanical in their approaches to Islamic theology and law. In matter of jurisprudence, Salafis and Wahhabis subscribe to the Hanbali mazhab (school of law) and law. (Ideologi Salafisme dan Wahhabisme dibangun di atas teks keagamaan yang difahami secara sempit. Secara metodologis, mereka adalah kalangan yang menganut pendekatan literalis dan puritan dalam hal teologi dan hukum Islam. Dalam hal hukum Islam, Salafi dan Wahhabi pada umumnya menganut Mazhab Hanbali).

Gambaran di atas memberikan sedikit pemahaman tentang apakah Salafisme sebagai orientasi keagamaan itu. Lebih detail lagi, dalam berbagi studi dan kajian, sejumlah ciri salafisme diungkapkan. Di antara ciri-ciri salafisme 
adalah: a) penolakan atas segala sesuatu yang berbau bid'ah pada doktrin dan praktik beragama di kalangan umat Islam; b) penolakan terhadap penafsiran hukum Islam oleh mazhab apapun termasuk empat mazhab fikih, dan sebagai alternatifnya mengajukan penafsiran dan pemahaman literal atas al-Qur'an dan Sunnah; c) prinsip yang kaku dalam hal pakaian dan penampilan (jenggot bagi laki-laki dan cadar bagi perempuan); d) penolakan pada segala sesuatu yang oleh penafsiran literal Qur'an cenderung akan ditolak, seperti foto, musik, bank konvensional, dan pemilihan umum; e) Salafisme juga menolak afiliasi pada organisasi dalam bentuk apapun, karena kesetiaan kepada organisasi akan menjauhkan Muslim dari Islam (ICG, 2004: 1-3).

Pembatasan seperti ini tentu saja masih mengundang perdebatan. Tetapi sekurang-kurangnya, apa yang dimaksudkan dengan salafisme itu bisa sedikit terungkap. Sekali lagi dalam konteks salafisme sebagai orientasi pemikiran. Dalam konteks sebagai orientasi pemikiran keagamaan ini sarjana-sarjana Barat pada abad ke-20 dan 21 cenderung memiliki pemahaman yang kurang tepat terhadap istilah salafi. Sebagaimana diidentifikasi oleh Frank Giffel (2015), di mata para sarjana Barat, salafi seringkali diartikan sebagai: a) gerakan pembaruan Islam yang didirikan oleh Jamal al-Din al-Afghani dan Muhammad Abduh; dan b) salafisme dihubungkan dengan gerakan pembaruan Islam yang melakukan kritik terhadap manifestasi Islam Sunni yang didasarkan pada Sufisme, teologi Asy'ariyah dan afiliasi pada mazhab fikih yang empat.

Tentu contoh-contoh penjelasan tentang anatomi gerakan salafisme sebagai orientasi pemikiran keagamaan di atas belum memadai. Tetapi, dari beberapa pandangan tentang ciri-ciri salafisme di atas, mari kita gunakan sebagai parameter untuk mengukur tren salafisme di Muhammadiyah.

Sebagai orientasi pemikiran keagamaan, salafisme menolak segala sesuatu yang berbau bid'ah. Sekilas, tentu saja doktrin ini sejalan dengan doktrin dasar Muhammadiyah yang menolak segala bentuk bid'ah. Salah satu doktrin penting Muhammadiyah adalah pemberantasan takhayul, bid'ah dan khurafat yang lazim dikenal dengan akronim TBC. Namun tentu saja, harus dilihat lebih dalam tentang hakikat penolakan bid'ah oleh Muhammadiyah dan salafisme. Di atas telah disinggung pula bahwa salah satu ciri orientasi keagamaan salafisme adalah kaku dan sempit dalam memaknai doktrindoktrin keagamaan. Dengan sendirinya, itu juga berlaku pada cara salafisme memahami bid'ah. 
Sebaliknya, doktrin anti-bid'ah Muhammadiyah tidak bisa difahami sematamata dalam kaitannya dengan bid'ah an sich dalam maknanya yang sempit, tetapi harus pula dihubungkan sikap Muhammadiyah terhadap realitas sosial, modernitas dan pembaruan pemikiran keagamaan. Maka dari situ akan tergambar dengan jelas bagaimana sesungguhnya faham antibid'ah Muhammadiyah berbeda dengan salafisme. Benar bahwa dalam Muhammadiyah, menghindari bid'ah merupakan satu kata kunci yang membedakan Muhammadiyah dengan gerakan lainnya. Namun, sepanjang yang saya fahami dan saksikan, bid'ah yang dimaksudkan dalam konteks Muhammadiyah adalah hal-hal yang berkaitan dengan ibadah. Maka, sepanjang menyangkut ibadah, jika tidak ditemukan contoh dari Rasulullah, ibadah itu haram atau terlarang. Satu kaidah fikih yang bisa digunakan untuk menggambarkan sikap Muhammadiyah ini adalah: al-ashlu fi al-ibadati al-tahrim bahwa hukum asal ibadah adalah terlarang sampai ada dalil yang menunjukkan kepada kewajibannya.

Di sisi lain, teramat jelas bahwa Muhammadiyah tidak menganut prinsip bid'ah dalam hal inovasi sosial sebagaimana diyakini oleh kalangan salafi. Kalangan salafi cenderung defensif terhadap inovasi sosial. Sementara salah satu letak rahasia kelanggengan gerakan Muhammadiyah hingga hari ini, adalah karena iovasi-inovasi sosial yang dikembangkan oleh Muhammadiyah ketika berhadapan dengan berbagai realitas masyarakat yang berubah. Dalam hal ini, barangkali kalimat yang tepat untuk menggambarkan prinsip Muhammadiyah adalah sebagaimana ungkapan Muhammad Ridla Abd alAlim al-Kafrawi dan Abd al-Aziz Abd al-Ghaffar al-Syadzili Laisa Kulla Jadadin Bid'atun, tidak semua yang baru adalah bid'ah. Inovasi sosial yang dijalankan oleh Muhammadiyah tentu adalah bid'ah dalam arti yang lughawi dan sempit, jika bid'ah dimaknai semata-mata sebagai hal yang tidak ada pada masa Nabi Muhammad SAW.

Sikap terhadap teks adalah contoh lain yang bisa digunakan untuk membandingkan Muhammadiyah dan salafisme. Salafisme hanya mengenal satu orientasi, yaitu literalisme. Sementara dalam Muhammadiyah aneka ragam pendekatan pada teks bisa ditemukan. Dengan menggunakan kerangka teori Abdullah Saeed, sikap umat Islam terhadapat teks ada tiga, yakni literalis, kontekstualis dan semi-kontekstualis. Jika dipelajari lebih mendalam, ketiga orientasi itu sama-sama bisa ditemukan di Muhammadiyah. Maka mereka yang menganut pendekatan literalis berarti memiliki titik singgung dengan salafisme. Sementara pendekatan semi-kontekstual dan kontekstual 
sama sekali tidak memiliki persinggungan dengan salafisme. Padahal kita tahu, Kiai Dahlan mempraktikkan pendekatan kontekstual dalam menafsirkan al-Qur'an, dan hingga hari ini pendekatan kontekstual masih merupakan pendekatan dominan dalam pembacaan al-Qur'an di kalangan Muhammadiyah. ${ }^{* * *}$ 


\section{Daftar Pustaka}

Biyanto, "Tren Salafisme di Muhammadiyah" (pwmu.co, 16/09/2019).

Robby Karman, Membentengi Muhammadiyah dari Paham Salafi (ibtimes.id, 26 September 2019).

Nurbani Yusuf, Manhaj Salafi Anti-Tesis Manhaj Muhammadiyah (ibtimes.id, 07/10/2019)

Nurbani Yusuf, Salafi Hari ini adalah Utsaiminiyah (ibtimes.id, 08/10/2019).

Nurfarid,Islam Reformis: Dari Salafi Tekstual ke Salafi Rasional (ibtimes.id, 02/10/2019).

Hasnan Bachtiar Lima Varian Salafisme di Indonesia.

Muhammad Said Ramadhan al-Buthi, al-Salafiyah: Marhalah Zamaniyyah Mub\rakah La Mazhabun Islamiyyun(Bairut: Dar al-Fikr al-Mu'ashir, 2010),

Abd-u-LLah bin Abd al-Rahm al-Bukhari, Mi Hiya al-Salafiyyah?(Kairo: Jumhuriyah Misr alArabiyah, 2012).

al-Allamah Syaikh Muhammad Amman al-Sifat al-Ilahiyyah fi Dhaw'i al-Kitabi wa Sunnati(Madinah: al-Jami'ah al-Islamiyyah bi al-Madinah al-Munawwarah, $1408 \mathrm{H}$ ).

Mohammed bin Ali dan Muhammad Saiful Alam Shah bin Sudiman (2016), Salafis and Wahhabis: Two Sides of the Same Coin? (Singapore: RSIS, 2016).

International Crisis Group, "Indonesian Backgrounder: Why Salafism and Terrorism Mostly Don't Mix,” ICG Asia Report No. 83 (Brussel: International Crisis Group, 2004).

Frank Griffel, "What Do We Mean By 'Salafi'? Connecting Muhammad Abduh with Egypt Nur Party in Islam's Contemporary Intellectual History,” Die Welt Des Islams 55 (2015), h. 186-220. 